\title{
Pengaruh Model Problem Based Instruction Berbantuan Media Lingkungan terhadap Kemampuan Berpikir Kritis IPA
}

\author{
Ni Pt. Nuristya Dewi ${ }^{1}$, I Ngh. Suadnyana ${ }^{2}$, Ni Wyn. Suniasih ${ }^{3}$ \\ Jurusan Pendidikan Dasar, \\ Universitas Pendidikan Ganesha, Singaraja, Indonesia \\ e-mail: putu.nuristya.dewi@undiksha.ac.id ${ }^{1}$, i.nengah.suadnyana@undiksha.ac.id ${ }^{2}$, \\ ni.wayan.suniasih@undiksha.ac.id ${ }^{3}$
}

\begin{abstract}
Abstrak
Penelitian ini bertujuan untuk mengetahui perbedaan yang signifikan kemampuan berpikir kritis IPA siswa kelas IV yang dibelajarkan melalui model problem based intruction berbantuan media lingkungan dengan kelompok siswa yang dibelajarkan melalui pembelajaran konvensional kelas IV SD Gugus Untung Surapati Denpasar Timur Tahun Ajaran 2018/2019. Jenis penelitian ini merupakan penelitian eksperimen semu dengan rancangan penelitian nonequivalent control group desaign. Populasi pada penelitian ini adalah seluruh kelas IV SD Gugus Untung Surapati Denpasar Timur Tahun Ajaran 2018/2019 berjumlah 212 orang. Teknik penentuan sampel penelitian ini adalah teknik random sampling dengan pengacakan kelas yang sudah ada tanpa membuat kelas baru, kemudian dilakukan pengundian penentuan kelompok sampel penelitian. Hasil pengundian diperoleh kelas IV SD Negeri 6 Sumerta sebanyak 37 orang sebagai kelompok eksperimen, dan kelas IV SD Negeri 9 Sumerta sebanyak 36 orang sebagai kelompok kontrol. Pengumpulan data kemampuan berpikir kritis IPA siswa menggunakan teknik tes, dengan menggunakan tes esai sebanyak 9 butir soal yang sudah divalidasi. Hasil perhitungan rata-rata gain skor ternormalisasi kelompok eksperimen adalah 0,094 dengan kategori rendah, sedangkan rata-rata gain skor ternormalisasi kelompok kontrol adalah 0,063 dikategorikan rendah. Hasil analisis uji-t menunjukkan $t_{\text {hitung }}=2,384>t_{\text {tabel }}$ (taraf signifikasi $5 \%$ dengan $\mathrm{dK}=71$ ) $=2,000$, berarti terdapat perbedaan yang signifikan kemampuan berpikir kritis IPA kelompok eksperimen dengan kelompok kontrol. Sehingga disimpulkan model Problem Based Instruction berbantuan media lingkungan berpengaruh terhadap kemampuan berpikir kritis IPA siswa kelas IV SD Gugus Untung Surapati Denpasar Timur Tahun Ajaran 2018/2019. Untuk peneliti yang memiliki kesamaan variabel, hasil penelitian ini dapat dipergunakan sebagai kajian penelitian relevan.
\end{abstract}

Kata kunci: PBI, lingkungan, berpikir kritis

\begin{abstract}
This study aims to determine the significant differences in science critical thinking skill of fourth-grade students learned through the Problem Based Instruction model assisted by environmental media with groups of students who are taught conventional learning of fourth grade SD Untung Surapati East Denpasar 2018/2019 Academic Year.This type of research is quasi-experimental research with the design non-equivalent control group research design. The population in this study were all fourth-grade of SD Untung Surapati East Denpasar 2018/2019 Academic Year totaling 212 people. The technique of determining the sample of this study is the random sampling tehnicque with randomization of existing classes without creating a new class, then drawing the determination of the study sample group. The drawing results were obtained by class IV SD Negeri 6 Sumerta as many as 37 people as the experimental group, and class IV SD Negeri 9 Sumerta as many as 36 people as the control group. The data collection of students critical thinking skill in IPA using test techniques is an essay test as 9 items that have been validated. The calculation results of the average gain normalized score of the experimental group are 0,094 categorized as a low, while the average gain of the normalized control group score is 0,063 categorized in a low. The result of the $t$-test analysis showed count $=2,384>t_{\text {table }}$ (a significance level $5 \%$ with $d K=71$ ) $=2,000$, meaning that there was a significant difference in the critical thinking in IPA of the experimental group with the control group. So it was concluded that the model of Problem Based Instruction assisted by environmental media had an effect on the critical thinking skill in IPA the students grade IV SD Untung Surapati's Group East Denpasar Academic Year 2018/2019. So it was concluded that the model of Problem Based
\end{abstract}


Instruction assisted by environmental media had an effect on the critical thinking skill in IPA the students grade IV SD Untung Surapati's Group East Denpasar Academic Year 2018/2019. For researchers who have similiar variabels, the results of this study can be used as relevant research studies.

Keywords: $P B I$, environmental, critical thinking

\section{Pendahuluan}

Kegiatan pembelajaran sebaiknya dapat menciptakan suasana belajar yang kondusif kepada peserta didik. Pembelajaran di sekolah saat ini sudah berkembang dari pembelajaran yang bersifat tradisional menjadi pembelajaran yang modern. Kegiatan pembelajaran tidak hanya sekedar kegiatan mengajar, melainkan menjadi kegiatan pembelajaran yang lebih kompleks dengan kegiatan pembelajaran bervariasi agar dapat membentuk siswa yang cerdas, dan mampu mengembangkan potensi yang dimiliki siswa.

Upaya memperoleh pembelajaran yang berkualitas dalam rangka mewujudkan tujuan pendidikan nasional, dapat dimulai dari sekolah dasar sebagai landasan pengembangan pendidikan selanjutnya. Sekolah dasar juga merupakan landasan pembentukan karakter yang mempunyai peran penting dalam meningkatkan kemampuan siswa pada ranah kognitif, afektif, dan psikomotorik sehingga dalam kegiatan pembelajaran harus dikelola dengan efektif melalui bimbingan dan pembelajaran yang tepat.

Salah satu cara menciptakan pembelajaran yang efekif adalah dengan melaksanakan pembelajaran terpadu yang telah dijalankan di Indonesia sesuai kurikulum yang berlaku. Kurikulum yang berlaku saat ini adalah kurikulum 2013 yaitu menerapkan pembelajaran tematik terpadu dengan pendekatan saintifik. Pembelajaran dengan pendekatan saintifik ini merupakan pembelajaran yang meliputi kegiatan mengamati, menanya, mengasosiasi/menalar, mengumpulkan informasi dan mengkomunikasikan. Istilah pendekatan saintifik ini lebih sering dikenal dengan pendekatan $5 \mathrm{M}$. Pendekatan saintifik dirancang agar siswa aktif selama proses pembelajaran. Dalam pendekatan saintifik siswa mendapatkan pengalaman belajar sehingga berdampak baik dalam jangka waktu panjang.

Tidak hanya menggunakan konsep pembelajaran terpadu, diperlukan juga model pembelajaran yang dapat membuat siswa akif, berpikir kritis, mampu memecahkan masalah nyata dalam kesehariannya. Keberhasilan suatu pembelajaran dapat dilakukan dengan menentukan model pembelajaran yang bervariasi dan efektif. Model pembelajaran yang bervariasi ini dimaksudkan dapat menciptakan pembelajaran yang menyenangkan sehingga siswa lebih mudah memperoleh informasi dan memahami informasi dalam waktu jangka panjang. Sehingga perlu juga diperhatikan dalam pemilihan model pembelajaran agar dapat menciptakan pembelajaran yang efektif.

Pemanfaatan sumber belajar di sekitar siswa seperti halnya lingkungan dapat digunakan untuk menunjang pembelajaran agar dapat menciptakan suasana yang kondusif untuk siswa. Lingkungan dapat digunakan sebagai media pembelajaran, karena lingkungan merupakan salah satu wahana atau alat yang membantu menyalurkan informasi secara nyata dan langsung kepada siswa. Pembelajaran dengan berbantuan sebuah media dapat menciptakan sebuah pengalaman belajar yang bermakna bagi siswa karena memacu siswa untuk belajar dan dilatih untuk memecahkan permasalahan yang ada di sekitar. Pembelajaran yang memanfaatkan lingkungan memiliki kemampuan untuk membangun fungsi struktur kognitif siswa secara lebih optimal sehingga berkesan lama dalam ingatan. Media lingkungan yang digunakan dalam membantu proses pembelajaran dapat meningkatkan kemampuan berpikir kritis pada siswa.

Kemampuan berpikir sangat memiliki banyak manfaat bagi manusia dalam proses pemecahan masalah di kehidupan seahari-hari. Kemampuan berpikir kritis termasuk salah satu jenis kemampuan berpikir. Berpikir kritis adalah suatu karakteristik yang sangat bermanfaat bagi siswa dalam melaksanakan pembelajaran di sekolah, karena dalam berpikir kritis mencakup kegiatan dalam pemecahan masalah, menganalisis suatu asumsi, memberi rasional, melakukan investigasi, mengevaluasi dan mengambil keputusan. Menurut Susanto (2013) "Berpikir kritis adalah suatu kegiatan tentang ide atau gagasan yang menghubungkan konsep yang diberikan dengan masalah yang terjadi". Kemampuan berpikir kritis sebaiknya dikembangkan sejak dini melalui pembelajaran, yaitu salah satunya dalam muatan materi IPA. Dalam muatan materi IPA 
terdapat banyak konsep atau masalah yang ada di lingkungan siswa sehari-hari sehingga dapat mengembangkan kemampuan berpikir kritis. Dengan melatih dan membiasakan siswa berpikir kritis, siswa mampu membedakan antara informasi yang baik dan buruk serta dapat mengambil keputusan yang tepat dan tanggung jawab terhadap informasi yang diperoleh melalui berpiki kritis.

Berdasarkan hasil observasi pembelajaran dan informasi yang diperoleh dari ketua gugus, kepala sekolah serta guru-guru khususnya wali kelas IV SD Gugus Untung Surapati Denpasar Timur yang dilakukan pada hari Kamis, 22 November 2018 terdapat berbagai permasalahan yang telah terjadi di lapangan yaitu, suasana pembelajaran yang kurang kondusif sehingga pembelajaran dirasa belum menciptakan suasana yang menyenangkan dilihat dari kurangnya ada respon dari siswa seperti jarang mengajukan pertanyaan dalam pembelajaran.

Masih kurang dimanfaatkan media-media pembelajaran yang terdapat di sekitar siswa dan selama pembelajaran lebih sering menggunakan buku dan papan tulis sebagai media dan sumber belajar siswa. Model pembelajaran yang kurang bervariatif menyebabkan suasana pembelajaran menjadi pasif karena lebih sering menggunakan pendekatan saintfik. Selain itu, sarana dan prasarana yang terdapat di sekolah belum dimanfaatkan dengan baik sehingga dapat pula menyebabkan pembelajaran kurang kondusif dan siswa kurang termotivasi dalam pembelajaran. Berdasarkan hal-hal yang telah dipaparkan tersebut, kendala-kendala dan permasalahan yang terjadi dapat mempengaruhi kemampuan berpikir kritis siswa kurang berkembang secara optimal.

Pemilihan model pembelajaran juga memiliki dampak terhadap kemampuan berpikir kritis siswa. Melalui pemilihan model pembelajaran yang dapat mengoptimalkan kemampuan berpikir kritis siswa adalah problem based instruction. Problem based instruction atau disingkat PBI merupakan suatu model pembelajaran berpusat pada siswa yang melibatkan siswa dalam pemecahan masalah yang dihadapi, seperti kemampuan mengajukan permasalahan, merumuskan masalah, mengumpulkan dan menganalisis data, menarik kesimpulan, berdiskusi dan berkomunikasi. Melalui model problem based instruction siswa terbiasa aktif untuk berpikir kritis karena mengalami keterlibatan secara mental dan terampil fisik sehingga dapat tercapainya tujuan belajar dan melatih mengembangkan kemampuan berpikir kritis siswa sejak dini dalam pembelajaran. Keunggulan model problem based instruction ini adalah sebuah model pembelajaran yang lebih menekankan makna, meningkatkan pengarahan diri, pemahaman yang lebih tinggi dan keterampilan yang lebih baik. Model pembelajaran berdasarkan masalah merupakan salah satu model pembelajaran yang efektif untuk pembelajaran proses berpikir tingkat tinggi

Dalam penelitian ini diterapkan model problem based instruction berbantuan media lingkungan. Melalui media lingkungan dapat menciptakan pembelajaran yang bermakna dan menjadi wahana siswa untuk mengembangkan potensi, pengalaman belajar siswa, kemampuan berpikir kritis dan menciptakan kondisi belajar yang kondusif sehingga berdampak dalam jangka waktu yang lama. Penggunaan media lingkungan yang ada disekitar siswa dapat dijadikan sumber belajar yang menarik sehingga siswa terlibat langsung secara fisik dan mental. Pembelajaran dibantukan oleh sebuah media lingkungan bukan berarti sebuah pembelajaran yang mengharuskan siswa belajar di luar kelas. Penerapan model problem based instruction berbantuan media lingkungan membantu siswa untuk memproses informasi yang sudah ada dalam benaknya dan dapat mengembangkan kemampuan berpikir kritis siswa. Menurut Arief (dalam Susanto: 2013) untuk melatih siswa kemampuan berpikir kritis terdapat beberapa kegiatan atau tahapan yang dapat dilakukan yaitu: a) kemampuan menganalisis, yaitu kegiatan yang bertujuan memahami konsep secara terperinci, b) kemampuan menyintetis yaitu kemampuan yang menggabungkan beberapa bagiaan menajadi satu bagian atau susunan baru, c) kemampuan memecahkan masalah merupakan kemampuan yang menuntut sesorang untuk memahami lebih kritis sehingga dari pemahaman tersebut menemui sebuah ide atau konsep baru, d) kemampuan menyimpulkan yaitu kemampuan seseorang dapat menguraikan berbagai konsep secara bertahap agar dapat menentukan sebuah simpulan, e) kemampuan mengevaluasi yaitu kemampuan yang menuntut pemikiran yang matang dalam menentukan nilai sesuatu dengan berbagai kriteria. Upaya dalam meningkatkan kemampuan berpikir kritis dapat dilakukan dengan cara melibatkan ke dalam pembelajaran berpusat kepada siswa salah satu dalam model pembelajaran berdasarkan masalah. Model problem based instruction dibantu dengan media lingkungan dapat membuat siswa berlatih untuk menggunakan berbagai konsep, prinsip dan keterampilan yang telah dipelajari untuk dapat memecahkan masalah 
dalam kehidupan sehari-hari dan terbiasa untuk melatih kemampuan berpikir kritis, dan dapat membuat siswa mampu memecahkan masalah yang dihadapi dalam kehidupan sehari-hari.

Berdasarkan uraian sebelumnya, maka dilakukan penelitian yang berjudul Pengaruh Model Problem Based Instruction Berbantuan Media Lingkungan Terhadap Kemampuan Berpikir Kritis IPA Siswa Kelas IV SD Gugus Untung Surapati Denpasar Timur Tahun Ajaran 2018/2019. Tujuan penelitian ini adalah a) mendeskripsikan kemampuan berpikir kritis IPA siswa yang dibelajarkan melalui model problem based instruction berbantuan media lingkungan pada siswa kelas IV SD Gugus Untung Surapati Denpasar Timur Tahun Ajaran 2018/2019, b) mendeskripsikan kemampuan berpikir kritis IPA siswa yang dibelajarkan melalui pembelajaran konvensional pada siswa kelas IV SD Gugus Untung Surapati Denpasar Timur Tahun Ajaran 2018/2019, c) untuk mengetahui perbedaan signifikan kemampuan berpikir kritis IPA siswa yang dibelajarkan melalui model problem based instruction berbantuan media lingkungan dengan siswa yang dibelajarkan melalui pembelajaran konvensional pada siswa kelas IV SD Gugus Untung Surapati Denpasar Timur Tahun Ajaran 2018/2019.

\section{Metode}

Penelitian dilaksanakan di sekolah negeri yang berada di Gugus Untung Surapati Denpasar Timur dengan menggunakan Kurikulum 2013 yaitu pada SD Negeri 6 Sumerta dan SD Negeri 9 Sumerta yang ada di Gugus Untung Surapati Denpasar Timur. Penelitian ini dilaksanakan pada semester II atau semester genap tahun ajaran 2018/2019. Peneliti memulai penelitian dari bulan November 2018 sampai dengan bulan Mei 2019.

Penelitian yang dilaksanakan ini merupakan penelitian kuantitafif dengan jenis penelitian eksperimen semu (quasi experiment). Desain ini memiliki kelompok kontrol, tetapi tidak dapat berfungsi sepenuhnya mengontrol variabel-variabel luar yang mempengaruhi pelaksanaan eksperimen. Desain eksperimen yang digunakan adalah nonequivalent control group desaign. Diformulasikan sebagai berikut.

\begin{tabular}{|ccc|}
\hline $\mathrm{O}_{1}$ & $\mathrm{X}$ & $\mathrm{O}_{2}$ \\
\hline & & \\
$\mathrm{O}_{3}$ & & $\mathrm{O}_{4}$ \\
\hline
\end{tabular}

Gambar 1. Rancangan Desain Penelitian

(Sumber : Sugiyono, 2017: 116)

Keterangan

$\mathrm{X}=$ Perlakuan

$\mathrm{O}_{1} \quad=\quad$ Pre-test pada kelompok ekperimen

$\mathrm{O}_{2} \quad=\quad$ Post-test pada kelompok ekperimen

$\mathrm{O}_{3} \quad=\quad$ Pre-test pada kelompok kontrol

$\mathrm{O}_{4}=$ Post-test pada kelompok control

Pada nonequivalent control group desaign ini terdapat dua kelompok yaitu, kelompok eksperimen dan kelompok kontrol. Sebelum diberikannya perlakuan pada kelompok eksperimen, maka kelompok eksperimen dan kelompok kontrol diberikan pre-test. Kemudian diberikan perlakuan kepada kelompok eksperimen yaitu dengan memberi perlakuan model problem based instruction berbantuan media lingkungan. Setelah diberikan perlakuan pada kelompok eksperimen dan kelompok kontrol diberikan post-test untuk mengetahui kemampuan berpikir kritis IPA.

Penelitian ini melewati langkah-langkah penelitian yang terdiri dari tiga tahap yaitu: tahap persiapan. Pada tahap pertama disebut tahap persiapan yang terdiri dari kegiatan antaralain: a) melakukan wawancara dengan kepala sekolah dan wali kelas IV di masing-masing SD Gugus Untung Surapati Denpasar Timur untuk mengetahui ada atau tidaknya kelas unggulan di gugus tersebut, b) melakukan pengundian untuk menentukan kelompok eksperimen dan kelompok 
kontrol, c) mempersiapkan sarana pendukung yang telah disesuaikan dengan pembelajaran saat penelitian, d) memperisapkan model problem based instruction yang digunakan pada kelompok eksperimen, e) mengkonsultasikan instrumen penelitian pre-test dan post-test bersama dosen pembimbing, f) mengadakan uji coba sekaligus pemberian pre-test, g) melalukan uji penyetaraa kedua kelompok sampel. Kemudian pada tahap selanjutnya adalah tahap pelaksanaan yaitu antaralain: 1) memberikan perlakuan pada kelompok eksperimen berupa model problem based instruction berbantuan media lingkungan, 2) memberikan perlakuan sebanyak 6 kali pada kelompok eksperimen dan memberikan pembelajaran konvensional pada kelompok kontrol, 3) memberikan post-test pada kelompok eksperimen dan kontrol, dan pada tahap terakhir adalah tahap akhir yaitu melakukan analisis data hasil penelitian dan melakukan uji hipotesis.

Dalam penelitian sangat perlu pemilihan populasi untuk dijadikan fokus penelitian yang nantinya akan ditarik kesimpulan. Menurut Sugiyono (2017: 117) "populasi adalah wilayah generalisasi yang terdiri atas obyek atau subyek yang mempunyai kualitas dan karakteristik tertentu yang ditetapkan oleh peneliti untuk dipelajari dan kemudian ditarik kesimpulannya". Menurut Koyan (2012: 30) "populasi adalah himpunan dari unsur-unsur yang sejenis". Sehingga dapat dirangkum pengertian populasi adalah keseluruhan obyek atau subyek yang meliputi keseluruhan karakteristik atau sifat yang dimilki oleh subjek atau objek tersebut kemudian ditarik kesimpulan untuk dijadikan data dalam penelitian.

Berdasarkan hasil wawancara dan observasi sebelum melaksanakan penelitian, SD Gugus Untung Surapati terdiri dari 11 sekolah dasar yaitu 6 SD Negeri dan 4 SD Swasta. Melihat dari segi fisik sekolah terdapat perbedaan yaitu fasilitas yang digunakan di antara sekolah berbeda-beda. Begitupula dilihat dari segi akademik, terlihat penggunaan kurikulum dan jam belajar sangat berbeda yaitu sekolah swasta menerapkan sistem belajar one full day school dan sekolah negeri tidak menerapkan sistem tersebut. Sehingga melihat dari perbedaan inilah, peneliti membatasi popolasi penelitian yaitu hanya menggunakan populasi pada SD Negeri di Gugus Untung Surapati Denpasar Timur karena sangat memiliki porposi kesaamaan dilihat dari segi fisik sekolah, fasilitas sekolah dan akademik sekolah. Masing-masing SD Negeri di Gugus Untung Surapati Denpasar Timur yaitu kelas IV dari 6 sekolah dengan 6 kelas yang ada di Gugus Untung Surapati Denpasar Timur setara secara akademik yang memiliki nilai ratarata tidak jauh berbeda yang dapat diartikan setara. Dikatakan setara, karena pengelompokan siswa ke dalam kelas-kelas dari 6 sekolah yang ada disebar secara merata antara siswa yang memiliki kemampuan tinggi, sedang, dan rendah. Dari keterangan tersebut dapat diartikan kelompok populasi setara secara akademik dilihat dari tidak terdapat kelas unggulan maupun non unggulan. Maka populasi dalam penelitian yang akan dilaksanakan ini adalah seluruh kelas IV SD Negeri di Gugus Untung Surapati Denpasar Timur tahun ajaran 2018/2019 yang terdiri dari 6 kelas dalam 6 sekolah dengan jumlah populasi dari penelitian ini sebanyak 212 orang siswa.

Setelah menentukan populasi penelitian kemudian dilakukan penentuan sampel penelitian. Menurut Sugiyono (2017: 117) "sampel adalah bagian dari jumlah dan karakteristik yang dimiliki oleh populasi tersebut". Sedangkan menurut Sudaryono (2016: 120) "sampel merupakan suatu bagian dari populasi". Sehingga dapat dirangkum pengertian sampel adalah kelompok yang lebih kecil atau bagian dari populasi yang memiliki karakteristik dari populasi yang diambil dengan menggunakan teknik tertentu. Penentuan sampel atau teknik pengambilan sampel pada penelitian ini menggunakan teknik random sampling. Pada teknik ini dilakukan penentuan sampel ini tidak dilakukannya pengacakan individu, tetapi pengacakan kelas. Sampel yang terpilih dalam penelitian ini adalah SD Negeri 6 Sumerta sebagai kelompok eksperimen dan SD Negeri 9 Sumerta sebagai kelompok kontrol. Adapun cara pengundian yang dilakukan dengan menulis semua nama kelas IV di seluruh SD Negeri yang menjadi populasi pada masing-masing kertas yang jumlah 6 kelas, kemudian kertas tersebut digulung. Gulungan kertas tersebut dimasukkan ke dalam kotak dan selanjutnya diundi. Gulungan kertas pertama yang diambil dari kotak ditetapkan menjadi kelas eksperimen. Selanjutnya dilakukan hal yang sama untuk menentukan kelas kontrol. Dari hasil pengundian sampel maka terpilih secara undi yaitu SD Negeri 6 Sumerta sebagai kelas kelompok eksperimen dan SD Negeri 9 Sumerta sebagai kelas kelompok kontrol.

Untuk memperoleh kelas yang ekuivalen dari segi akademik, maka dua kelas sampel yang terpilih diberikan pre-test. Menurut Dantes (2017: 125) "Pemberian pre-test biasanya digunakan untuk mengukur ekuivalensi atau penyetaraan kelompok" dapat diartikan skor hasil pre-test bertujuan untuk kesetaraan sampel dan mengukur kemampuan awal sampel. Setelah diberikan pre-test data dari kedua kelompok tersebut diuji kesetaraan menggunakan uji-t. 
Sebelum menganalisis kesetaraan, data pre-test kedua kelompok sampel terlebih dahulu memenuhi uji prasyarat normalitas sebaran data dengan teknik Kolmogorov-Smirnov dan homogenitas varians dengan Uji Fisher $(F)$. Setelah data hasil pre-test memenuhi uji prasyarat normalitas sebaran data kemudian dilanjutkan dengan uji-t untuk menguji kedua kelompok setara atau tidak setara.

Salah satu faktor yang mempengaruhi hasil penelitian adalah validitas internal. Validitas internal bersumber dari pelaksanaan penelitian ini sendiri yang berkaitan dengan perlakuan yang diberikan apakah perlakuan yang diberukan benar-benar menyebabkan hasil observasi yang diobservasi dalam penelitian. Validitas internal dalam penelitian ini yaitu sejarah, testing, pengaruh penggunaan instrumen dan karakteristik subjek. Selain faktor internal, ada faktor lain yang bersifat eksternal yang memiliki pengaruh pada hasil penelitiannya yaitu validitas eksternal yaitu terdiri dari interaksi antara perlakuan dan orang, serta interaksi antara perlakuan dan latar.

Metode pengumpulan data merupakan sesuatu hal yang penting, karena metode merupakan cara yang digunakan untuk mengumpulkan data yang diperlukan dalam penelitian. Metode pengumpulan data uang digunakan dalam penelitian ini adalah tes. Tes yang digunakan mengumpulkan data kemampuan berpikir kritis IPA yaitu tes esai. Tes esai berujuan mengukur kemampuan memahami, aplikasi dan analisis. Paling bagus digunakan untuk mengukur kemampuan menyatakan pendapat, menyusun ide dan memecahkan masalah.

Uji validitas pada penelitian ini digunakan adalah uji validitas isi dan validitas butir. Validitas isi dipandang dari segi isi alat ukur sendiri, berdasarkan materi yang disampaikan dalam pembelajaran dan dikuasai oleh peserta didik. Tujuan dari validitas isi untuk merepresentasikan dengan baik tes yang hendak diukur, caranya dapat dilakukan dengan membandingkan tes dengan kisi-kisi tes. Untuk mengukur validitas butir tes dalam bentuk tes esai digunakan rumus korelasi Product Moment $\left(r_{\mathrm{xy}}\right)$. Suatu butir insrumen penilaian dikatakan reliabel apabila dipakai mengukur pada waktu yang berlainan hasilnya akan sama. Dengan demikian, reliabilitas dapat pula diartikan dengan keajegan atau stabilitas. Uji reliabilitas dilakukan terhadap butir soal yang valid saja, dengan demikian uji reliabilitas bisa dilakukan setelah dilakukan uji validitas. Untuk uji reliabilitas mempergunakan rumus Alpha Cronbach.

Data pada penelitian ini menggunakan data gain skor ternormalisasi dari hasil pre-test dan hasil post-test yang telah didapatkan. Skor pada hasil pre-test dan post-test diambil dari sampel penelitian, yaitu kelas eksperimen dan kelas kontrol yang ternormalisasi. Pada penelitian ini dilakukan analisis statistik deskriptif dan analisis statistik inferensial. Metode analisis data statistik deskriptif digunakan untuk mendeskripsikan data kemampuan berpikir kritis IPA siswa yang dibelajarkan dengan model problem based instruction berbantuan media lingkungan dan data kemampuan berpikir kritis IPA siswa yang dibelajarkan dengan pembelajaran konvensional. Analisis statistik deskriptif yang digunakan dalam penelitian ini, yaitu penghitungan rata-rata, standar deviasi dan varians. Pada analisis statistik ini digunakan untuk menganalisis data sampel dan hasilnya digeneralisasikan atau diinferensikan kepada populasi yang sampel tersebut telah diambil. Dalam statistik ini digunakan uji-t (t-test), uji-t digunakan karena data yang terkumpul sudah memenuhi uji prasyarat analisis, yaitu uji normalitas sebaran data dan uji homogenitas varians. Apabila data telah berdistribusi normal dan homogen, analisis dilanjutkan dengan uji hipotesis yaitu menggunakan uji-t polled varians. Rumus uji-t dengan rumus polled varians digunakan karena jumlah anggota sampel tidak sama $\mathrm{n}_{1} \neq \mathrm{n}_{2}$ dan varians homogen dengan $\mathrm{dK}\left(\mathrm{n}_{1}+\mathrm{n}_{2}\right)$-2 (Koyan, 2012: 41), dengan kriteria $\mathrm{t}_{\text {hitung }}>$ $t_{\text {tabel }}$, maka $\mathrm{H}_{0}$ diterima pada taraf signifikansi $5 \%$.

\section{Hasil dan Pembahasan}

Jenis penelitian yang digunakan adalah quasi eksperimen dengan desain penelitian yaitu nonequivalent control group desaign. Sedangkan untuk data yang dianalisis adalah data kemampuan berpikir kritis IPA siswa kelas IV pada kelompok eksperimen dan kelompok kontrol. Setelah dilakukan pengundian sampel, ditetapkan seluruh siswa kelas IV SD Negeri 6 Sumerta menjadi kelompok eksperimen, sedangkan seluruh siswa kelas IV SD Negeri 9 Sumerta menjadi kelompok kontrol. Kelas eksperimen diberikan perlakuan sebanyak 6 kali dengan menerapkan model pembelajaran problem based instruction berbantuan media lingkungan, sedangkan kelas kontrol hanya dibelajarkan secara konvensional sebanyak 6 kali.

Sebelum diberikannya perlakuan setelah melakukan pre-test maka dilakukan analisis data pre-test yang bertujuan untuk mengetahui ada atau tidaknya kesetaraan dalam kelompok sampel. Analisis uji kesetaraan sampel dilakukan menggunakan uji-t. Sebelum dilakukan analisis pada uji-t, data harus melewati uji prasyarat yaitu uji normalitas sebaran data dan uji 
homogenitas, karena data telah melewati uji prasyarat maka dapat dilanjutkan dengan kesetaraan dengan menggunakan uji-t. Berdasarkan uji analisis diperoleh $t_{\text {hitung }}=1,922<t_{\text {tabel }}=$ 2,000 pada taraf signifikansi $5 \% \mathrm{dk}=71$ yang artinya kedua kelompok sampel setara. Adapun rekapitulasi hasil analaisis uji kesetaraan sebagai berikut.

Tabel 1. Rekapitulasi Hasil Uji-t dari Data Pre-test Kemampuan Berpikir Kritis IPA Sampel Penelitian

\begin{tabular}{cccccccc}
\hline No. & Sampel & $\mathbf{N}$ & $\overline{\mathbf{X}}$ & $\mathbf{S}^{2}$ & $\mathbf{t}_{\text {hitung }}$ & $\mathbf{t}_{\text {tabel }}$ & Simpulan \\
\hline 1 & Kelas & 37 & 30,730 & 34,42 & 1,922 & 2,000 & Sampel Setara \\
2 & $\begin{array}{c}\text { Eksperimen } \\
\text { Kelas Kontrol }\end{array}$ & 36 & 28,194 & 29,00 & & & \\
\hline
\end{tabular}

Penelitian perlu menyajikan hasil analisis dalam bentuk deskripsi data variabel terikat yang berupa tabel distribusi, histogram atau yang lainnya dan dilengkapi dengan interpretasi data disesuaikan dengan desain penelitian. Data yang diperoleh dalam penelitian ini dikelompokkan menjadi dua yaitu; (1) data kemampuan berpikir kritis IPA kelompok kelas eksperimen, (2) data kemampuan berpikir kritis IPA kelompok kelas kontrol. Deskripsi data hasil kemampuan berpikir kritis IPA siswa yang dipaparkan meliputi nilai rerata, standar deviasi dan varians. Kelas IV SD Negeri 6 Denpasar Timur yang terpilih secara acak sebagai kelompok eksperimen setelah 6 kali penerapan RPP, diukur kemampuan berpikir kritis IPA melalui pretest dan post-test kemudian dicari gain skor yang ternormalisasi. Mendeskripsikan data gain skor ternormalisasi kelompok eksperimen dilakukan dengan mencari mean, standar deviasi dan varians. Hasil penghitungan mean kemudian diinterpretasikan ke dalam tabel kriteria peningkatan gain skor.

Tabel 2. Deskripsi Data Gain Skor Ternormalisasi Kelompok Eksperimen

\begin{tabular}{ll}
\hline Mean & 0,094 \\
Standar Deviasi & 0,060 \\
Varians & 0,004 \\
\hline
\end{tabular}

Berdasarkan hasil penghitungan, diperoleh mean kelompok eksperimen adalah 0,094 yang kemudian diinterpretasi ke dalam rekapitulasi kriteria peningkatan gain skor, sehingga dapat dikategorikan dalam kategori yang rendah. Kelas IV SD Negeri 9 Denpasar Timur yang terpilih secara acak sebagai kelompok kontrol yang dibelajarkan menggunakan pembelajaran konvensional sebanyak 6 kali, diukur kemampuan berpikir kritis IPA melalui pre-test dan posttest yang kemudian dicari gain skor yang ternormalisasi. Mendeskripsikan data gain skor kelompok kontrol dilakukan dengan mencari mean, standar deviasi dan varians. Hasil penghitungan mean kemudian diinterpretasikan ke dalam tabel kriteria peningkatan gain skor.

Tabel 3. Deskripsi Data Gain Skor Ternormalisasi Kelompok Kontrol

\begin{tabular}{ll}
\hline Mean & 0,063 \\
Standar Deviasi & 0,051 \\
Varians & 0,003 \\
\hline
\end{tabular}

Berdasarkan hasil penghitungan mean, diperoleh mean kelompok eksperimen adalah 0,063 yang kemudian diinterpretasi ke dalam rekapitulasi kriteria peningkatan gain skor, sehingga dapat dikategorikan mengalami peningkatan yang rendah. Data yang digunakan untuk menganalisis kemampuan berpikir kritis IPA adalah data gain skor ternormalisasi hasil pre-test dan post-test. Sebelum dilakukan uji analisis maka data harus melewati uji prasyarat. Uji prasyarat dalam penelitian dilakukan sebagai syarat yang digunakan untuk statistik parametrik seperti pengujian hipotesisi dengan menggunakan uji-t. Uji prasyarat pada penelitian ini dilakukan setelah diperoleh gain skor yang ternormaliasasi dikedua kelompok yaitu kelompok eksperimen dan kelompok kontrol. Uji prasyarat tersebut, terdiri dari uji normalitas sebaran data dengan teknik Kolmogorov-Sminrov dan uji homegenitas varians dengan uji Fisher (F).

Berdasarkan hasil penghitungan tabel kerja uji normalitas sebaran data kelompok eksperimen diperoleh nilai $\left|\mathrm{F}_{\mathrm{T}}-\mathrm{Fs}\right|$ maksimum yaitu 0,150 . Nilai tersebut digunakan sebagai 
angka penguji normalitas sebaran data pada taraf signifikan $5 \%$ dengan $n=37$. Diperoleh nilai tabel Kolmogorov-smirnov yaitu 0,218, sehingga hasil penghitungan $0,150<0,218$ artinya sebaran data kelompok eksperimen berdistribusi normal. Kemudian, berdasarkan hasil penghitungan tabel kerja uji normalitas sebaran data kelompok kontrol diperoleh nilai $\left|F_{T}-F s\right|$ maksimum yaitu 0,199 . Nilai tersebut digunakan sebagai angka penguji normalitas sebaran data pada taraf signifikan $5 \%$ dengan $\mathrm{n}=36$ Diperoleh nilai tabel Kolmogorov-smirnov yaitu 0,221 sehingga hasil penghitungan $0,199<0,221$ artinya sebaran data kelompok kontrol berdistribusi normal. Setelah melakukan uji normalitas sebaran data maka dilanjutkan dengan analisis homogenitas varians. Berdasarkan hasil penghitungan varians nilai gain skor kelompok sampel, diperoleh varians kelompok eksperimen 0,004 dan varian kelompok kontrol 0,003. Adapun nilai $\mathrm{F}_{\text {tabel }}$ pada taraf signifikansi $5 \%$ dengan $\mathrm{dk}_{1}$ pembilang $=36$ dan $\mathrm{dk}_{2}$ penyebut $=35$ adalah 1,750. Sehingga $F_{\text {hitung }}=1,333<F_{\text {tabel }}=1,750$ artinya data kelompok eksperimen dan kelas kontrol memiliki varians yang homogen.

Pada tahap selanjutnya adalah tahap uji-t karena data sudah melewati uji prasyarat yaitu uji normalitas sebaran data dan uji homogenitas varians. Berdasarkan penghitungan diperoleh $t_{\text {hitung }}=2,384>t_{\text {tabel }}=2,000$ pada taraf signifikansi $5 \%$ dengan $\mathrm{dk}=71$ yang artinya $\mathrm{H} 0$ ditolak . Berikut rekapitulasi hasil analisis uji-t.

Tabel 4. Rekapitulasi Hasil uji-t dari Data Gain Skor Ternormalisasi Kemampuan Berpikir Kritis IPA

\begin{tabular}{llllllll}
\hline No. & Kelompok Sampel & $\mathbf{n}$ & $\bar{X}$ & $\mathbf{S}^{2}$ & $\mathbf{t}_{\text {hitung }}$ & $\mathbf{t}_{\text {tabel }}$ & Simpulan \\
\hline 1 & Kelompok eksperimen & 37 & 0,094 & 0,004 & & & \\
2 & Kelompok kontrol & 36 & 0,063 & 0,003 & & & \\
\hline
\end{tabular}

Hal ini berarti terdapat perbedaan yang signifikan kemampuan berpikir kritis IPA siswa yang dibelajarakan melalui model problem based instruction berbantuan media lingkungan dengan kelompok siswa yang dibelajarkan melaui model konvensional kelas IV SD Gugus Untung Surapati Denpasar Timur Tahun Ajaran 2018/2019.

Berdasarkan hasil penghitungan uji kesetaraan data pre-test diperoleh kedua kelompok setara. Kemudian diberikan perlakuan berupa penerapan model problem based instruction berbantuan media lingkungan pada kelompok eksperimen diperoleh perbedaan gain skor ternormalisasi kemampuan berpikir kritis IPA. Gain skor ternormalisasi kemampuan berpikir kritis IPA pada kelompok eksperimen lebih tinggi dari gain skor kemampuan berpikir kritis IPA pada kelompok kontrol. Perbedaan tersebut terlihat dari rata-rata gain skor ternormalisasi kemampuan berpikir kritis IPA yang diberikan perlakuan model problem based instruction berbantuan media lingkungan lebih tinggi dari rata-rata gain skor ternormalisasi kemampuan berpikir kritis IPA yang dibelajarkan dengan pembelajaran konvensional.

Pada kelompok eksperimen, penerapan model problem based insruction berbantuan media lingkungan dapat memberikan kemudahan kepada siswa untuk memecahkan permasalahan yang sedang dialami dalam lingkungan sekitarnya, karena melalui model problem based instruction berbantuan media lingkungan kelompok kecil-kecil siswa bekerja sama memecahkan suatu masalah. Selain itu dengan penerapan model problem based instruction dapat meningkatkan kemampuan berpikir dan pemecahan masalah siswa. Dalam penerapan model pembelajaran problem based instruction dibantukan dengan media lingkungan yang dapat membuat pembelajaran lebih bermakna dan dapat dijadikan sebagai wahana untuk mengembangkan kemampuan berpikir kritis IPA, dengan adanya media lingkungan dalam pembelajaran memberikan siswa turuf aktif dan siswa mendapat pengalaman baru yaitu hal-hal baru yang bermakna dan menjadi sumber belajar baru.

Dalam 6 kali perlakuan dengan menerapkan RPP model problem based instruction berbantuan media lingkungan dirasa belum optimal dalam meningkatkan perkembangan kemampuan berpikir kritis IPA siswa dilihat dari analisis statistik deskriptif dengan perolehan rata-rata gain skor ternormalisasi termasuk dalam kategori peningkatan rendah, yang artinya dengan penerapan model problem based instruction berbantun media lingkungan belum optimal dalam mengembangkan kemampuan berpikir kritis IPA. Upaya yang dapat dilakukan dalam mengembangkan kemampuan berpikir kritis IPA siswa yaitu dengan memberikan perlakuan lebih dari 6 kali secara berkala. Dengan membiasakan siswa terlibat secara langsung 
dan aktif dalam pembelajaran dapat mengoptimalkan perkembangan kemampuan berpikir kritis IPA siswa. Kemampuan berpikir kritis IPA dapat dikembangkan dengan cara membiasakan siswa memecahkan masalah yang ada di lingkungan sekitar dalam kehidupan sehari-hari agar dapat mengoptimalkan kemampuan berpikir kritis IPA siswa. Selain itu dapat dilakukan upayaupaya untuk mengoptimalkan kemampuan berpikir kritis IPA dalam pembelajaran adalah dengan melakukan peningkatan daya analisis dalam diskusi kelompok. Siswa dibiasakan terlibat langsung dalam diskusi kelompok dengan mengarahkan pada penyelesaian atau solusi terbaik dalam permasalahan. Selain itu dapat membiasakan untuk mengembangkan kemampuan mengobservasi atau mengamati dalam kegiatan pembelajaran, dalam kegiatan mengamati siswa telah menggali kemampuan berpikirnya ke tingkat yang lebih tinggi atau kemampuan berpikir kritis. Maka dengan upaya-upaya pembiasaan tersebut dapat mengoptimalkan kemampuan berpikir kritis IPA siswa.

\section{Simpulan dan Saran}

Kemampuan berpikir kritis dapat lahir dan berkembang di setiap individu apabila terus dilatih, salah satunya dilatih sejak dini dalam pembelajaran. Berpikir kritis dapat dikembangkan dalam muatan pelajaran IPA karena dalam pelajaran muatan IPA banyak konsep atau permasalahan dalam lingkungan siswa yang dapat dijadikan suatu objek untuk menumbuhkan kemampuan berpikir yang lebih kritis. Pembelajaran di kelas harus dapat merangsang kemampuan berpikir kritis siswa, maka diperlukan juga sebuah model pembelajaran yang dapat menumbuhkembangkan kemampuan berpikir kritis IPA siswa. Salah satunya adalah model Problem Based Instruction merupakan salah satu model pembelajaran yang berdasarkan masalah yang dapat memperoleh dan mengembangkan kemampuan berpikir kritis siswa. Melalui kegiatan pembelajaran berdasarkan masalah apabila siswa terus dilatih dengan pemecahan masalahan maka siswa akan dapat mengembangkan kemampuan berpikir yang lebih kritis. Oleh karenanya model problem based instruction adalah model pembelajaran yang menitikberatkan pada masalah sebagai bahan pembelajaran. Selain penggunaan model problem based instruction untuk membantu siswa dalam proses pemecahan masalah, dengan dibantukan media pembelajaran dapat membuat pembelajaran lebih bermakna. Penggunaan media lingkungan sebagai media pembelajaran yang membantu dalam proses pembelajaran dapat membuat siswa bebas menyalurkan kreativitas dan dirasa media lingkungan menjadi wahana untuk mengembangkan potensi siswa. Pembelajaran dengan memanfaatkan media lingkungan dapat membangun makna belajar yang lebih kuat dan berfungsi mengembangkan ranah kognitif siswa.

Penelitian ini bertujuan untuk 1) mendeskripsikan kemampuan berpikir kritis IPA yang dibelajarkan dengan model problem based instruction berbantuan media lingkungan siswa kelas IV SD Gugus Untung Surapati Denpasar Timur Tahun Ajaran 2018/2019, 2) mendeskripsikan kemampuan berpikir kritis IPA yang dibelajarkan dengan pembelajaran konvensional siswa kelas IV SD Gugus Untung Surapati Denpasar Timur Tahun Ajaran $2018 / 2019$, 3) untuk mengetahui perbedaan yang signifikan kemampuan berpikir kritis IPA antara siswa yang dibelajarkan menggunakan model problem based instruction berbantuan media lingkungan dengan kelompok siswa yang dibelajarkan menggunakan pembelajaran konvensional pada siswa kelas IV SD Gugus Untung Surapati Denpasar Timur tahun ajaran 2018/2019. Manfaat penelitian ada dua, yakni manfaat teoritis dan manfaat praktis. Manfaat praktis ada empat, yakni manfaat bagi siswa, bagi guru, bagi kepala sekolah dan peneliti lain.

Penlitian ini merupakan jenis penelitian quasi eksperiment (desain eksperimen semu) dengan rancangan desain yaitu nonequivalent control group design dan dilakukan tiga tahapan penelitian yaitu tahap persiapan, tahap pelaksaan dan tahap akhir. Populasi dalam penelitian ini adalah seluruh siswa kelas IV SD Negeri Gugus Untung Surapati Denpasar Timur Tahun Ajaran 2018/2019 yang terdiri dari 6 sekolah yaitu SD Negeri 4 Sumerta, SD Negeri 6 Sumerta, SD Negeri 7 Sumerta, SD Negeri 9 Sumerta, SD Negeri 11 Sumerta dan SD Negeri 14 Dangin Puri dengan jumlah populasi yaitu 212 siswa. Pengambilan sampel dilakukan dengan teknik random sampling yaitu dengan pengacakan kelas. Penentuan kelompok sampel dilakukan dengan cara pengundian untuk menentukan kelompok eksperimen dan kelompok kontrol sehingga pengundian ini dilakukan sebanyak dua kali. Pengundian pertama dilakukan untuk menentukan kelompok eksperimen dan pengundian kedua dilakukan untuk menentukan kelompok kontrol. Sampel penelitian yang terpilih yaitu kelas IV SD Negeri 6 Sumerta dan kelas IV SD Negeri 9 Sumerta. Kedua kelas yang terpilih diberikan pre-test untuk mengukur kemampuan awal kedua 
sampel dan penyetaraan. Metode pengumpulan data yang digunakan adalah metode tes dengan instrumen yang digunakan adalah tes esai sebanyak 9 butir soal yang sudah divalidasi.

Setelah diberikan perlakuan sebanyak 6 kali, kemudian dilanjutkan dengan pemberian post-test untuk mengukur kemampuan berpikir kritis IPA siswa. Berdasarkan hasil analisis statistik deskriptif kemampuan berpikir kritis IPA pada kelompok eksperimen diperoleh rata-rata 0,094 . Rata-rata tersebut kemudian di konversikan pada tabel rekapitulasi kriteria peningkatan gain skor, sehingga kemampuan berpikir kritis IPA siswa kelas eksperimen memiliki katagori rata-rata yang lebih tinggi daripada kelompok kontrol. Berdasarkan hasil uji-t diperoleh $t_{\text {hitung }}=$ 2,384 . Nilai tersebut kemudian dibandingkan dengan $t_{\text {tabel }}$ pada taraf signifikansi $5 \%$ dengan $\mathrm{dk}$ $=71\left(t_{\text {tabel }}=2,000\right)$, hasilnya $t_{\text {hitung }}=2,384>t_{\text {tabel }}=2,000$ sehingga $H_{\circ}$ ditolak, yang berarti terdapat perbedaan yang signifikan kemampuan berpikir kritis IPA siswa kelas IV antara kelompok yang dibelajarkan dengan model problem based instruction berbantuan media lingkungan dan kelompok siswa yang dibelajarkan dengan model konvensional.

Adapun perolehan penghitungan rata-rata kemampuan berpikir kritis IPA siswa kelompok yang dibelajarkan melalui model problem based instruction berbantuan media lingkungan pada siswa kelas IV SD Gugus Untung Surapati Denpasar Timur Tahun Ajaran 2018/2019 adalah 0,094 Kemudian dikonversikan ke dalam rekapitulasi peningkatan gain skor untuk kelompok eksperimen, sehingga kemampuan berpikir kritis IPA siswa kelas eksperimen yang dibelajarkan melalui model problem based instruction berbantuan media lingkungan siswa kelas IV SD Gugus Untung Surapati Denpasar Timur Tahun Ajaran 2018/2019 termasuk kategori rendah. Kemudian perolehan penghitungan rata-rata kemampuan berpikir kritis IPA siswa kelompok yang dibelajarkan melalui model pembelajaran konvensional pada siswa kelas IV SD Gugus Untung Surapati Denpasar Timur Tahun Ajaran 2018/2019 adalah 0,063. Nilai tersebut kemudian dikonversikan pada tabel rekapitulasi peningkatan gain skor untuk kelompok kontrol, sehingga kemampuan berpikir kritis IPA siswa kelas kontrol yang dibelajarkan melalui model pembelajaran konvensional pada kelas IV SD Gugus Untung Surapati Denpasar Timur Tahun Ajaran 2018/2019 termasuk dalam kategori rendah. Kemudian, Rata-rata kemampuan berpikir kritis IPA kelompok yang dibelajarkan melalui model problem based instruction berbantuan media lingkungan yaitu $\bar{X}=0,094$ lebih besar dari kelompok yang dibelajarkan melalui pembelajaran konvensional yaitu $\bar{X}=0,063$. Hasil analisis data dengan uji-t diperoleh $\mathrm{t}_{\text {hitung }}=$ 2,384 pada taraf signifikansi $5 \%$ dan derajat kebebasan 71 sehingga diperoleh $t_{\text {tabel }}=2,000$, karena $t_{\text {hitung }}=2,384>t_{\text {tabel }}=2,000$ maka dapat diartikan terdapat perbedaan yang signifikan kemampuan berpikir kritis IPA antara kelompok yang dibelajarkan dengan model problem based instruction berbantuan media lingkungan dengan kelompok yang dibelajarkan dengan pembelajaran konvensional. Dari hasil analisis tersebut dapat disimpulkan bahwa model problem based instruction berbantuan media lingkungan berpengaruh terhadap kemampuan berpikir kritis IPA siswa kelas IV SD Gugus Untung Surapati Denpasar Timur Tahun Ajaran $2018 / 2019$.

\section{Daftar Pustaka}

Dantes, N. 2017. Desain Eksperimen dan Analisis Data. Singaraja: Rajawali Pers

Koyan, I Wayan. 2012. Statistik Pendidikan Teknik Analisis Data Kuantitatif. Singaraja: UniversitasPendidikan Ganesha Press

Sudaryono. 2016. Metode Penelitian Pendidikan.Tangerang: Prenada Media Group

Sudijono, Anas. 2015. Pengantar Evaluasi Pendidikan. Yogyakarta: Rajawali Pers

Sugiyono. 2017a. Metode Penelitian Pendidikan. Bandung: Alfabeta

Sugiyono. 2017b. Statistika untuk Penelitian. Bandung: Alfabeta

Susanto, Ahmad. 2013. Teori Belajar \& Pembelajaran di Sekolah Dasar. Jakarta: Prenada Media Group 